\title{
Carbonic anhydrase inhibitors. Inhibition of the $\beta$-class enzymes from the fungal pathogens Candida albicans and Cryptococcus neoformans with branched aliphatic/aromatic carboxylates and their derivatives
}

\author{
Fabrizio Carta ${ }^{\mathrm{a}}$, Alessio Innocenti ${ }^{\mathrm{a}}$, Rebecca A. Hall ${ }^{\mathrm{b}}$, Fritz A. Mühlschlegel ${ }^{\mathrm{b}}$, Andrea Scozzafava $^{\mathrm{a}}$, \\ Claudiu T. Supuran ${ }^{\mathrm{a}, *}$ \\ ${ }^{a}$ Università degli Studi di Firenze, Laboratorio di Chimica Bioinorganica, Rm. 188, Via della Lastruccia 3, I-50019 Sesto Fiorentino (Firenze), Italy \\ ${ }^{\mathrm{b}}$ School of Biosciences, University of Kent, Canterbury, Kent CT2 7NJ, United Kingdom
}

\section{A R T I C L E I N F O}

Article history:

Received 28 December 2010

Revised 10 February 2011

Accepted 12 February 2011

Available online 17 February 2011

\section{Keywords:}

Carbonic anhydrase

Carboxylate

Inhibitor

$\beta$-Class enzyme

Antifungals

Candida albicans

Cryptococcus neoformans

\begin{abstract}
A B S T R A C T
The inhibition of the $\beta$-carbonic anhydrases (CAs, EC 4.2.1.1) from the pathogenic fungi Cryptococcus neoformans (Can2) and Candida albicans (Nce103) with a series of 25 branched aliphatic and aromatic carboxylates has been investigated. Human isoforms hCA I and II were also included in the study for comparison. Aliphatic carboxylates were generally millimolar hCA I and II inhibitors and low micromolar/ submicromolar $\beta$-CA inhibitors. Aromatic carboxylates were micromolar inhibitors of the four enzymes but some of them showed low nanomolar activity against the fungal pathogenic enzymes. 4-Hydroxyand 4-methoxy-benzoate inhibited Can2 with $K_{\mathrm{I}} \mathrm{s}$ of 9.5-9.9 nM. The methyl esters, hydroxamates, hydrazides and carboxamides of some of these derivatives were also effective inhibitors of the $\alpha$ - and $\beta$-CAs investigated here.
\end{abstract}

(c) 2011 Elsevier Ltd. All rights reserved.
In previous work, the inhibition of various carbonic anhydrases (CAs, EC 4.2.1.1) with a small number of carboxylates (C1-C5 aliphatic derivatives and several intermediates of the Krebs cycle) has been investigated. ${ }^{1,2}$ These compounds are interesting as they are a chemotype quite different from the sulfonamides, which are the main class of inhibitors of these metalloenzymes and have the potential to have specificity for the $\beta$-class CAs which are predominantly found in microorganisms and not vertebrates, over the $\alpha$-class enzymes that are predominant in vertebrates, including humans. ${ }^{3,4}$

The $\beta$-CAs are the most common class of CA enzymes among the five genetically distinct families described so $\operatorname{far}(\alpha-, \beta-, \gamma-, \delta-$, and $\zeta$-CAs), and have been identified in various organisms all over the phylogenetic tree. ${ }^{3-5} \beta$-CAs have been described in a great number of species belonging to the Archaea and Bacteria domains, ${ }^{3,5}$ whereas in Eukaryotes only yeasts, microscopic fungi and very recently arthropods were shown to encode such enzymes. ${ }^{6-10} \mathrm{~A}$ high number of $\alpha$-CA isoforms (16 CAs in non-primates and 15 in primates), ${ }^{3}$ have been described and are well characterized for their fundamental physiological roles. ${ }^{3} \beta$-CAs were recently characterized

\footnotetext{
* Corresponding author. Tel.: +39 055 4573005; fax: +39 0554573385 .

E-mail address: claudiu.supuran@unifi.it (C.T. Supuran).
}

in a high number of human pathogens, such as the fungi/yeasts Candida albicans, Candida glabrata, Cryptococcus neoformans, Saccharomyces cerevisiae, ${ }^{8-11}$ and the bacteria Helicobacter pylori, Mycobacterium tuberculosis, Haemophilus influenzae, Brucella suis, Streptococcus pneumoniae. ${ }^{10-13}$ Their inhibition with various agents, such as sulfonamides, anions, carboxylates, and boronic acids, has been explored in some detail and for some of these enzymes. $^{8-17}$ Anti-infectives based on inhibition of $\beta$-CAs from pathogenic organisms have been proposed as alternative novel therapeutic agents to treat bacterial/fungal infections, ${ }^{3,6}$ considering that many of the clinically used agents targeting these pathogens led to serious resistance problems. ${ }^{3,6,16,17}$

One of the main problems in the design of CA inhibitors (CAIs) as therapeutic agents is the inability to selectively target pathogen's $\beta$-CA isoform without inhibiting the mammalian $\alpha$-CAs. To date, only the coumarins, ${ }^{18,19}$ which act as prodrugs, are true selective CAIs. ${ }^{18,19}$ The selectivity of this class of drugs is achieved by exploiting the esterase activity of the $\alpha$-class enzymes (present only for them and not for the $\beta-, \gamma$ - and $\zeta$-classes), ${ }^{20}$ to generate substituted 2-hydroxycinnamic acids, which occlude the entrance to the active site cavity. ${ }^{18-20}$

In order to find compounds selective for other CA families, we decided to explore a range of other chemotypes, such as carboxylic acids, boronic acids, small inorganic (metal-complexing) 
anions, phenols, etc., in addition to the sulfonamides and their

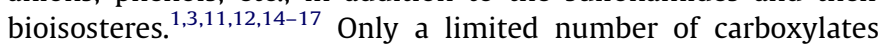
have been investigated up to now for the inhibition of the 16 mammalian $\alpha$-CA isoforms, ${ }^{1,3,14-17}$ and of the $\beta$-CAs from the pathogenic fungi C. albicans (Nce103) and C. neoformans (Can2), by these groups. ${ }^{1}$ The investigated carboxylates included the $\mathrm{C} 1-\mathrm{C} 5$ aliphatic derivatives, several intermediates of the Krebs cycle (pyruvic, lactic, malonic, maleic and citric acids) as well as two aromatic ones, benzoic acid and 2,3,5,6-tetrafluorobenzoic acid. ${ }^{1}$ In this Letter we extend the previous work, and investigate a series of 25 monocarboxylic acids, including branched C3-C12 aliphatic derivatives (compounds 1-11) and substituted benzoic acids (compounds 12-27) for their interactions with the two enzymes from the fungal pathogens mentioned above, as well as with the host, physiologically dominant enzymes hCA I and II ( $h=$ human isoform; the inhibition of these enzymes was also not reported up to now with the carboxylates investigated here). ${ }^{21,22}$ We also investigated whether derivatization of the $\mathrm{COOH}$ moiety (leading to methyl esters, hydroxamates, hydrazides and carboxamides) of some of these derivatives influences the CA inhibitory properties significantly.
$\beta$-CAs over human (h) hCA II, the physiologically dominant human isoform. For comparison reasons, hCA I and hCA II inhibition data with the same anions are provided. Indeed, hCA II is the best studied $\alpha$-CA, being ubiquitous in the human body and playing many important physiologic (or pathologic in cases of disbalances) functions. $^{3}$ Some of the hCA II inhibition data with these anions (e.g., formate, acetate, propionate and butyrate) were reported earlier, ${ }^{1 \mathrm{~b}}$ and are presented here for comparison reasons. The other data are new and are presented for the first time. Acetazolamide (5-acetamido-1,3,4-thiadiazole-2-sulfonamide) $\mathbf{A A Z}$, a clinically used CAI has also been investigated as standard inhibitor.

The following may be observed regarding the inhibition of hCA I, hCA II, Can2 and Nce103 with carboxylates 1-27 and some of the carboxylic acid derivatives investigated here:

(i) The slow, ubiquitous cytosolic ${ }^{3}$ isoform hCA I was weakly inhibited by the aliphatic carboxylates 1-11, as well as by formate, propionate and butyrate, with $K_{\mathrm{I}} \mathrm{s}$ generally in the millimolar range (101-1040 $\mu \mathrm{M})$. The best aliphatic carboxylate inhibitors of this isoform were acetate, valerate, 4-methylvalerate and 2-methylheptanoate, which showed $K_{\mathrm{I}} \mathrm{S}$ in the range of $10.8-98 \mu \mathrm{M}$. It is rather striking that there is no regularity in the inhibition pattern

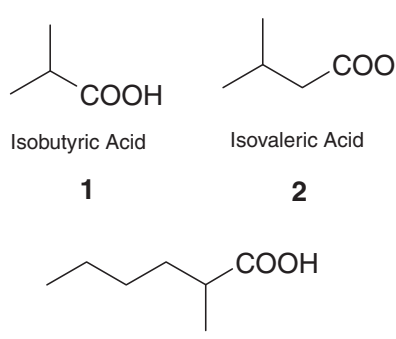

2-Methylexanoic Acid

6

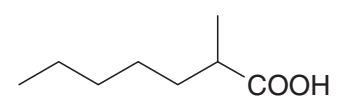

2-Methyleptanoic Acid

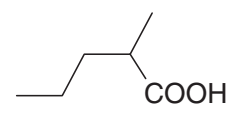

2-Methylvaleric Acid

3

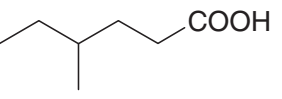

4-Methylexanoic Acid

7

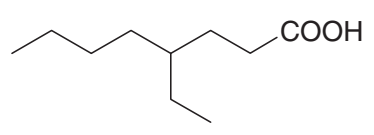

4-Ethyloctanoic Acid

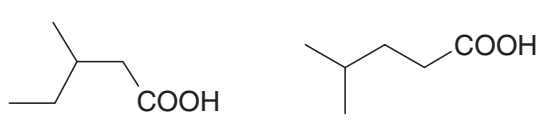

3-Methylvaleric Acid

4
4-Methylvaleric Acid

5<smiles>CCCCC(CC)C(=O)O</smiles>

2-Ethylexanoic Acid

8

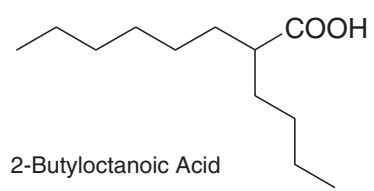

11<smiles>O=C(O)c1ccccc1</smiles>

12<smiles>O=C(O)c1c(F)c(F)cc(F)c1F</smiles>
13<smiles>COc1ccc(C(=O)O)cc1</smiles>

20<smiles>Nc1ccc(C(=O)O)cc1</smiles>

21<smiles>O=C(O)c1ccc(F)cc1</smiles>

14<smiles>O=C(O)c1ccc(Cl)cc1</smiles>

15<smiles>O=C(O)c1ccc(Br)cc1</smiles>

16<smiles>O=C(O)c1ccc(I)cc1</smiles>

17<smiles>O=C(O)c1ccc([N+](=O)[O-])cc1</smiles>

18<smiles>O=C(O)c1ccc(O)cc1</smiles>

19<smiles>N#Cc1ccc(C(=O)O)cc1</smiles>

22<smiles>NC(=O)c1ccc(C(=O)O)cc1</smiles>

24<smiles>O=C(O)c1ccc(CCl)cc1</smiles>

25<smiles>CN(C)c1ccc(C(=O)O)cc1</smiles>

26<smiles>O=C(O)c1ccc(S(=O)(=O)OCl)cc1</smiles>

27
Tables 1 and 2 show the inhibition data of the $\beta$-CAs from pathogenic fungi, Can2 and Nce103, with the carboxylates 1-27 mentioned above as well as selectivity ratios for the inhibition of the when passing from formate (very weak inhibitor, $K_{\mathrm{I}}$ of $1.04 \mathrm{mM}$ ) to acetate (the best aliphatic inhibitor) and then to propionate (the same type of activity as formate, $K_{\mathrm{I}}$ of $1.01 \mathrm{mM}$ ). However 
Table 1

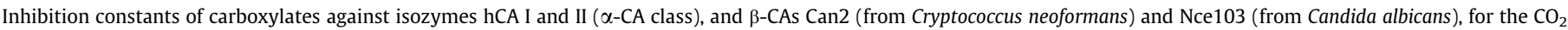
hydration reaction, at $20^{\circ} \mathrm{C}^{22}$

\begin{tabular}{|c|c|c|c|c|c|c|c|}
\hline \multirow[t]{2}{*}{ No. } & \multirow[t]{2}{*}{ Inhibitor $^{\S}$} & \multicolumn{4}{|c|}{$K_{\mathrm{I}}^{\#}(\mu \mathrm{M})$} & \multicolumn{2}{|c|}{ Selectivity ratios } \\
\hline & & $\mathrm{hCA} \mathrm{I}^{\mathrm{a}}$ & hCA II ${ }^{\mathrm{a}}$ & Can $2^{\mathrm{b}}$ & Nce $103^{b}$ & hCA II/Can2 & hCA II/Nce103 \\
\hline- & Formate & 1040 & $24000^{c}$ & $53.5^{\mathrm{c}}$ & $35.1^{\mathrm{c}}$ & 448 & 683 \\
\hline- & Acetate & 10.8 & $130^{c}$ & $7.3^{c}$ & $36.0^{\mathrm{c}}$ & 17.8 & 3.61 \\
\hline- & Propionate & 1010 & $960^{c}$ & $404^{c}$ & $51.5^{\mathrm{c}}$ & 2.37 & 18.6 \\
\hline- & Butyrate & 511 & $1032^{\mathrm{c}}$ & $225^{c}$ & $26.9^{c}$ & 4.58 & 34.8 \\
\hline- & Valerate & 55.3 & $257^{c}$ & $42.8^{c}$ & $94.0^{c}$ & 6.00 & 2.73 \\
\hline 1 & Isobutyrate & 120 & 350 & 3.81 & 0.98 & 91.8 & 357.0 \\
\hline 2 & Isovalerate & 300 & 100 & 0.91 & 0.95 & 109.9 & 105.2 \\
\hline 3 & 2-Methylvalerate & 310 & 113 & 10.2 & 10.4 & 11.0 & 10.8 \\
\hline 4 & 3-Methylvalerate & 104 & 281 & 34.9 & 11.1 & 8.05 & 25.3 \\
\hline 5 & 4-Methylvalerate & 98 & 320 & 5.33 & 2.14 & 60.0 & 149.5 \\
\hline 6 & 2-Methylhexanoate & 380 & 103 & 3.23 & 3.73 & 31.8 & 27.6 \\
\hline 7 & 4-Methylhexanoate & 420 & 112 & 0.80 & 1.25 & 140.0 & 89.6 \\
\hline 8 & 2-Ethylhexanoate & 450 & 93 & 0.95 & 43.1 & 97.9 & 2.15 \\
\hline 9 & 2-Methylheptanoate & 92 & 110 & 39.3 & 11.7 & 2.79 & 9.40 \\
\hline 10 & 4-Ethyloctanoate & 380 & 96 & 41.2 & 37.9 & 2.33 & 2.53 \\
\hline 11 & 2-Buyloctanoate & 101 & 83 & 5.18 & 10.7 & 16.0 & 7.75 \\
\hline
\end{tabular}

Selectivity ratios for inhibition of $\beta$-CAs over hCA II are also given.

\# Errors were in the range of $3-5 \%$ of the reported values, from three different assays. ${ }^{22}$

$\S$ As sodium salt.

a Human cloned isoforms, assay at $\mathrm{pH} 7.5$ (Hepes buffer).

b This work, at pH 8.3 (Tris buffer), as $\beta$-CAs show low catalytic activity at pH values <8.0.

${ }^{\mathrm{c}}$ From Ref. 1.

\section{Table 2}

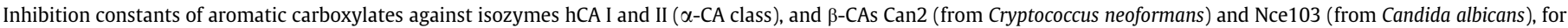
the $\mathrm{CO}_{2}$ hydration reaction, at $20^{\circ} \mathrm{C}^{22}$<smiles>NS(=O)(=O)c1nnc(NC(=O)c2ccccc2)s1</smiles>

12-27

AAZ

\begin{tabular}{|c|c|c|c|c|c|c|c|}
\hline \multirow[t]{2}{*}{ No. } & \multirow[t]{2}{*}{$\mathrm{R}^{\S}$} & \multicolumn{4}{|c|}{$K_{\mathrm{I}}^{\#}(\mu \mathrm{M})$} & \multicolumn{2}{|c|}{ Selectivity ratios } \\
\hline & & $\mathrm{hCA} \mathrm{I}^{\mathrm{a}}$ & hCA II ${ }^{\mathrm{a}}$ & $\mathrm{Can} 2^{\mathrm{b}}$ & Nce103 ${ }^{b}$ & hCA II/Can2 & hCA II/Nce103 \\
\hline 12 & $\mathrm{H}$ & 730 & $30^{c}$ & $1267^{c}$ & $24.4^{\mathrm{c}}$ & 0.02 & 1.23 \\
\hline 13 & $2,3,5,6-\mathrm{F}_{4^{-}}$ & 74 & $6^{c}$ & $49.1^{\mathrm{c}}$ & $61.6^{\mathrm{c}}$ & 0.12 & 0.09 \\
\hline 14 & $4-\mathrm{F}-$ & 7.39 & 3.34 & 0.13 & 1.09 & 25.7 & 3.06 \\
\hline 15 & $4-\mathrm{Cl}-$ & 7.61 & 3.81 & 3.40 & 2.65 & 1.12 & 1.43 \\
\hline 16 & $4-\mathrm{Br}-$ & 8.00 & 4.70 & 4.24 & 4.18 & 1.10 & 1.12 \\
\hline 17 & $4-I-$ & 8.18 & 5.85 & 5.46 & 5.17 & 1.07 & 1.13 \\
\hline 18 & $4-\mathrm{O}_{2} \mathrm{~N}-$ & 8.80 & 8.56 & 0.12 & 4.85 & 71.3 & 1.76 \\
\hline 19 & 4-HO- & 7.61 & 7.28 & 0.0095 & 0.11 & 766.3 & 66.2 \\
\hline 20 & 4-MeO- & 9.06 & 8.03 & 0.0099 & 0.15 & 811.1 & 53.5 \\
\hline 21 & $4-\mathrm{H}_{2} \mathrm{~N}-$ & 8.40 & 8.13 & 0.12 & 2.95 & 67.7 & 2.75 \\
\hline 22 & $3-\mathrm{H}_{2} \mathrm{~N}-$ & 8.79 & 8.63 & 3.06 & 3.40 & 2.82 & 2.53 \\
\hline 23 & $4-\mathrm{NC}-$ & 6.92 & 6.79 & 0.14 & 4.47 & 48.5 & 1.52 \\
\hline 24 & 4-AcHN- & 4.04 & 7.28 & 0.32 & 0.34 & 22.7 & 21.4 \\
\hline 25 & $4-\mathrm{ClCH}_{2}-$ & 3.88 & 4.36 & 3.65 & 4.71 & 1.19 & 0.92 \\
\hline 26 & $4-\mathrm{Me}_{2} \mathrm{~N}-$ & 3.94 & 3.33 & 0.13 & 5.20 & 25.6 & 0.64 \\
\hline 27 & $4-\mathrm{Cl}_{2} \mathrm{NSO}_{2}-$ & 3.88 & 1.96 & 0.12 & 4.97 & 16.3 & 0.39 \\
\hline $\mathrm{AAZ}$ & - & 0.25 & 0.012 & 0.010 & 0.13 & 1.20 & 0.09 \\
\hline
\end{tabular}

The standard sulfonamide inhibitor acetazolamide (AAZ) was also included as standard. Selectivity ratios for inhibition of $\beta$-CAs over hCA II are also given.

\# Errors were in the range of 3-5\% of the reported values, from three different assays. ${ }^{22}$

$\S$ As sodium salt.

${ }^{\text {a }}$ Human cloned isoforms, assay at pH 7.5 (Hepes buffer).

b This work, at $\mathrm{pH} 8.3$ (Tris buffer), as $\beta$-CAs show low catalytic activity at pH values $<8.0$.

c From Ref. 1.

the longer chain and branched carboxylate then showed a more regular inhibition pattern, most of them being weak inhibitors (Table 1 ). Considering the aromatic carboxylates (Table 2 ), it may be observed that benzoic acid $\mathbf{1 2}$ and its tetrafluoro derivative 13 are also rather ineffective inhibitors of this isoform $\left(K_{\mathrm{I}} \mathrm{S}\right.$ in the range of $74-730 \mu \mathrm{M}$ ), but all the remaining substituted benzoic acids 14-27 show effective, low micromolar inhibitory properties, with $K_{\mathrm{I}} \mathrm{S}$ in the range of $3.88-9.06 \mu \mathrm{M}$. The carboxylate moiety is known to bind zinc in monodentate fashion in $\alpha-\mathrm{CAs}^{23}$ (and also $\beta$-CAs). ${ }^{2}$ Indeed, in the hCA XIII ${ }^{23 a}$ and Can2 structures, an acetate ion was found bound monodentately, by means of one oxygen atom, to the catalytically crucial $\mathrm{Zn}(\mathrm{II})$ ion from the enzyme active 
site. The methyl group on the other hand made not any relevant interactions with amino acid residues from the active site, ${ }^{2,23}$ due to its small moiety. However, it is expected that carboxylates with a more complicated scaffold compared to acetate, will bind in the same way to the metal ion, by coordinating through the $\mathrm{COO}^{-}$zincbinding function, whereas the organic scaffold will interact with amino acid residues from the active site of the enzyme. This seems to be the case for the carboxylates investigated here. It may be observed from data of Tables 1 and 2 that these interactions seem to be rather unfavourable for the aliphatic derivatives, but much more favorable for the aromatic carboxylates 14-27.

(ii) The physiologically dominant cytosolic isoform hCA II was also weakly inhibited by the aliphatic, C1-C5 carboxylates (investigated earlier) ${ }^{1}$ as well as by compounds 1-11 investigated here, which showed $K_{\mathrm{I}} \mathrm{S}$ in the range of $83-350 \mu \mathrm{M}$ (Table 1 ). The best aliphatic hCA II inhibitors were 2-ethylhexanoate 8, 4-ethyloctanoate $\mathbf{1 0}$ and 2-butyloctanoate $\mathbf{1 1}\left(K_{\mathrm{I}} \mathrm{S}\right.$ in the range of $\left.83-96 \mu \mathrm{M}\right)$, whereas the least effective ones were $\mathbf{1}$ and $\mathbf{5}\left(K_{\mathrm{I}} \mathrm{S}\right.$ in the range of 320-350 $\mu \mathrm{M}$ ). Benzoic acid 12 was a medium potency inhibitor $\left(K_{\mathrm{I}}\right.$ of $\left.30 \mu \mathrm{M}\right)$ but its substituted derivatives 13-27 showed enhanced inhibition, with $K_{\mathrm{I}} \mathrm{S}$ in the range of $1.96-8.63 \mu \mathrm{M}$ (Table 2). Structure activity relationship (SAR) is not straightforward even for this subseries of derivatives: for example the highly electronegative substituents (4-F, 4-Cl) and electron withdrawing (4-chlorosulfonyl) moieties led to derivatives with comparable activity $\left(K_{\mathrm{I}} \mathrm{S}\right.$ of $1.96-3.81 \mu \mathrm{M}$ for 14,15 and 27). Thus, the $\mathrm{p} K_{\mathrm{a}}$ of the carboxylic acid is not the only factor influencing biological activity. Probably the various interactions in which all fragments present in the inhibitor scaffold participate with amino acid residues and water molecules from the active site influence the overall inhibitory capacity of these compounds.

(iii) The fungal enzyme from C. neoformans, Can2, showed an interesting inhibition profile with these carboxylates (Tables 1 and 2). Among the aliphatic derivatives investigated earlier, ${ }^{1}$ only acetate showed low micromolar inhibitory effects $\left(K_{\mathrm{I}}\right.$ of $\left.7.3 \mu \mathrm{M}\right)$, with the other anions being quite weak inhibitors $\left(K_{\mathrm{I}} \mathrm{S}\right.$ in the range of $42.8-404 \mu \mathrm{M})$. Among the branched aliphatic carboxylates investigated here, three derivatives, 4, 9 and 10, showed weak inhibitory activity, with $K_{\mathrm{I}} \mathrm{S}$ in the range of $34.9-41.2 \mu \mathrm{M}$. The remaining carboxylates, $\mathbf{1 - 3}, \mathbf{5 - 8}$ and $\mathbf{1 1}$, were more effective Can2 inhibitors, with $K_{\mathrm{I}} \mathrm{s}$ in the range of $0.80-10.2 \mu \mathrm{M}$ (Table 1 ). This is indeed a very interesting result, considering the fact that all these carboxylates are much weaker inhibitors of the human isoforms hCA I and II. For example, 4-methylhexanoate 7, with a $K_{\mathrm{I}}$ of $0.80 \mu \mathrm{M}$ for the inhibition of Can2, also has a selectivity ratio for inhibiting Can2 over hCA I of 525, and of 140 for inhibiting Can2 over hCA II. The selectivity ratios of 2-ethylhexanoate 8 are of 473 (Can2 over hCA I) and of 97.9 for inhibiting Can2 over hCA II (Table 1 ). The position of the branching from the carboxylate function and the size of the substituents thus significantly influenced the inhibitory power. For example, the isomeric acids $\mathbf{6}$ and $\mathbf{7}$ showed four times differences of activity for the inhibition of Can2. It may be also observed (Table 1 ) that the selectivity ratios for the inhibition of Can2 over hCA II for these aliphatic derivatives varies in a rather large range, between 2.33 (for 10) to 448 (for formate).

Whereas benzoic acid 12 and its tetrafluoroderivative 13 were shown $^{1}$ to be weak Can2 inhibitors ( $K_{\mathrm{I}} \mathrm{S}$ of $\left.48.1-1267 \mu \mathrm{M}\right)$, the substituted benzoates 14-27 showed highly enhanced inhibitory properties (Table 2). Thus, compounds 15-17 (containing heavy halogens), 22 (3-aminobenzoic acid) and 25 (4-chloromethyl derivative) were the weakest inhibitor in the series, with $K_{\mathrm{I}} \mathrm{S}$ in the range of $3.40-5.46 \mu \mathrm{M}$. Most of the remaining derivatives $(14,18,21,23,24,26$ and 27) showed strong Can2 inhibitory properties, with $K_{\mathrm{I}} \mathrm{S}$ in the range of $0.12-0.14 \mu \mathrm{M}$. Two derivatives, the 4-hydroxy- and 4-methoxy-benzoic acid $\mathbf{1 9}$ and $\mathbf{2 0}$ were on the other hand low nanomolar can2 inhibitors, with $K_{\mathrm{I}} \mathrm{S}$ of
9.5-9.9 nM (Table 2). As the selectivity ratios for inhibiting Can2 over hCA I and II were $>80$, it may be also concluded that these compounds are Can2-selective, highly potent inhibitors (no sulfonamides with this potency as Can2 inhibitors were detected so far). ${ }^{2}$ Thus, a rather large range of 4-substituted-benoic acids showed excellent Can2 inhibition and also a rather high degree of selectivity for the inhibition of the fungal over the host enzymes. Again the range of selectivity ratios for the inhibition of Can2 over hC II varies very much, between 0.02 (for 12) and 811.1 (for 20).

(iv) The fungal enzyme from C. albicans, Nce103, was weakly inhibited by the previously investigated ${ }^{1}$ aliphatic carboxylates, with $K_{\mathrm{I}} \mathrm{S}$ in the range of $26.9-94.0 \mu \mathrm{M}$, whereas the branched carboxylates 1-11 investigated here showed an enhanced activity (Table 1). Thus, two compounds, 8 and $\mathbf{1 0}$, were rather ineffective Nce103 inhibitors $\left(K_{\mathrm{I}} \mathrm{s}\right.$ of $\left.37.9-43.1 \mu \mathrm{M}\right)$ but the remaining aliphatic derivatives showed inhibition constants in the low micromolar range $\left(K_{\mathrm{I}} \mathrm{S}\right.$ of $\left.0.95-11.1 \mu \mathrm{M}\right)$. The best inhibitors in this subseries were isobutyrate 1 and isovalerate 2 ( $K_{\mathrm{I}} \mathrm{S}$ of $0.95-$ $0.98 \mu \mathrm{M}$ ) whereas the least effective ones the longer chain compounds 8-11. Thus, the SAR for the inhibition of Nce103 and Can2, two ortholog enzymes, is quite different with this class of CAIs (see discussion above for Can2 inhibition). For example, 8 was 45 times a better Can2 than Nce103 inhibitor (Table 1). However, as for Can2, the two benzoic acids 12 and 13 showed weak Nce103 inhibitory properties, with $K_{\mathrm{I}} \mathrm{S}$ of $24.4-61.6 \mu \mathrm{M}$. Selectivity ratios for inhibiting Nce103 over hCA II vary considerably from 2.15 (for 8) to 683 (for formate).

The substituted benzoates of type 14-27 investigated here showed effective inhibitory properties, with $K_{\mathrm{I}} \mathrm{S}$ in the range of 0.11-5.20 $\mu \mathrm{M}$. Again, many substitution patterns at the aromatic ring lead to effective CAIs, the best compounds being the 4-hydroxy-, 4-methoxy- and 4-acetamido-benzoic acids 19, 20 and 24, with $K_{\mathrm{I}} \mathrm{S}$ of $110-340 \mathrm{nM}$ (Table 2). The selectivity ratios for inhibiting Nce103 over hCA II were $<1$ for some of the investigated compounds (e.g., 13, 25-27 and acetazolamide) and varied between 1.52 and 66.2 for the remaining compounds (Table 2). SAR is not straightforward, as already discussed for the inhibition of other CAs with these compounds, and only the resolution of some X-ray structures of adducts of this enzyme with such carboxylates may shed some light in the drug design of carboxylate-based inhibitors of $\beta$-CAs.

(v) As the free carboxylic acids investigated here showed no antifungal activity in vivo (data not shown) we decided to investigate whether reducing their polar character by derivatization of the $\mathrm{COOH}$ moiety significantly influences the CA inhibitory properties. Thus, the methyl ester, hydroxamate, hydrazide and carboxamide of the aliphatic derivative $\mathbf{8}$ and the aromatic one $\mathbf{2 0}$ have been prepared ${ }^{24-26}$ and investigated for the inhibition of the four CAs (Table 3). To our greatest surprise, we noticed that this derivatizations lead to a significant increase of the hCA I and II inhibitory effects of the carboxylic acid derivatives over the free carboxylate, mainly for the aliphatic compounds 8a-8d. Indeed, they were one-two orders of magnitude better inhibitors compared to the free acid. For the aromatic acid derivatives 20a-20d, the enhancement of the inhibitory properties was observed but this is modest compared to the activity of the free acid (17-18 times for the hydroxamate $\mathbf{2 0 b}$ over the acid 20, for hCA I and II). As far as we know, this is the first study in which such an effect has been reported.

In the case of the pathogenic $\beta$-class enzymes Can 2 and Nce103, for the aliphatic acid derivatives $\mathbf{8 a - 8 b}$, an enhancement of the CA inhibitory properties has been also evidenced, which is rather modest for Can2 but high (in the range of 7-14 times) for Nce103 (Table 3). Indeed, for example the hydroxamate $\mathbf{8 b}$ was 14.1 times a better Nce103 inhibitor compared to the corresponding acid 8. However, for the aromatic derivatives 20a-20d, the 
Table 3

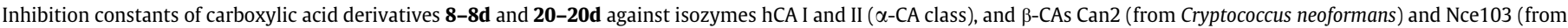
Candida albicans), for the $\mathrm{CO}_{2}$ hydration reaction, at $20^{\circ} \mathrm{C}^{22}$<smiles>CCCCC(CC)C(=O)O</smiles>

8 - 8d<smiles>COc1ccc(C(=O)O)cc1</smiles>

$20-20 d$

\begin{tabular}{|c|c|c|c|c|c|c|c|}
\hline \multirow[t]{2}{*}{ No. } & \multirow[t]{2}{*}{$\mathrm{X}$} & \multicolumn{4}{|c|}{$K_{\mathrm{I}}^{\#}(\mu \mathrm{M})$} & \multicolumn{2}{|c|}{ Selectivity ratios } \\
\hline & & $\mathrm{hCA} \mathrm{I}^{\mathrm{a}}$ & hCA II ${ }^{\mathrm{a}}$ & $\operatorname{Can} 2^{\mathrm{b}}$ & Nce103 ${ }^{\mathrm{b}}$ & hCA II/Can2 & hCA II/Nce103 \\
\hline 8 & $\mathrm{OH}$ & 450 & 93 & 0.95 & 43.1 & 97.9 & 2.15 \\
\hline $8 \mathbf{a}$ & OMe & 4.38 & 2.05 & 0.74 & 5.60 & 2.77 & 0.36 \\
\hline $\mathbf{8 b}$ & $\mathrm{NHOH}$ & 4.81 & 2.60 & 0.29 & 3.05 & 8.96 & 0.85 \\
\hline $8 c$ & $\mathrm{NHNH}_{2}$ & 8.51 & 2.17 & 0.23 & 4.56 & 9.43 & 0.47 \\
\hline 8d & $\mathrm{NH}_{2}$ & 6.48 & 3.45 & 0.39 & 5.70 & 8.84 & 0.60 \\
\hline 20 & $\mathrm{OH}$ & 9.06 & 8.03 & 0.0099 & 0.15 & 811.1 & 53.5 \\
\hline 20a & OMe & 3.84 & 3.53 & 0.067 & 0.61 & 52.7 & 5.78 \\
\hline $20 b$ & $\mathrm{NHOH}$ & 0.48 & 0.45 & 0.071 & 0.47 & 6.33 & 0.95 \\
\hline $20 c$ & $\mathrm{NHNH}_{2}$ & 7.84 & 5.75 & 0.087 & 0.81 & 66.1 & 7.09 \\
\hline 20d & $\mathrm{NH}_{2}$ & 4.34 & 2.18 & 0.062 & 0.54 & 35.2 & 4.03 \\
\hline
\end{tabular}

Selectivity ratios for inhibition of $\beta$-CAs over hCA II are also given.

\# Errors were in the range of $3-5 \%$ of the reported values, from three different assays. ${ }^{22}$

a Human cloned isoforms, assay at $\mathrm{pH} 7.5$ (Hepes buffer).

b This work, at pH 8.3 (Tris buffer), as $\beta$-CAs show low catalytic activity at pH values <8.0.

opposite was true, as the carboxylic acid derivatives were less effective Can2 and Nce103 inhibitors compared to the free acid 20. The loss of activity was however not very high (Table 3 ), and work is in progress in our laboratories to investigate whether such compounds may be effective as antifungals in vivo. The selectivity ratios for inhibiting Can2 over hCA II remained good for most of the new derivatives, but the Nce103 over hCA II selectivity ratios were less favorable for the aliphatic derivatives $\mathbf{8 a - 8 d}$, with all of them $<1$ (Table 3).

The proposed binding of one of the most effective CAIs detected here for the $\beta$-CAs, that is, 4-hydroxybenzoate $\mathbf{1 9}\left(K_{\mathrm{I}}\right.$ of $\left.9.5 \mathrm{nM}\right)$ to Can2, based on the X-ray crystal structure of the enzyme, ${ }^{2}$ is shown in Figure 1. The $\mathrm{Zn}(\mathrm{II})$ is coordinated by residues Cys68, His124,

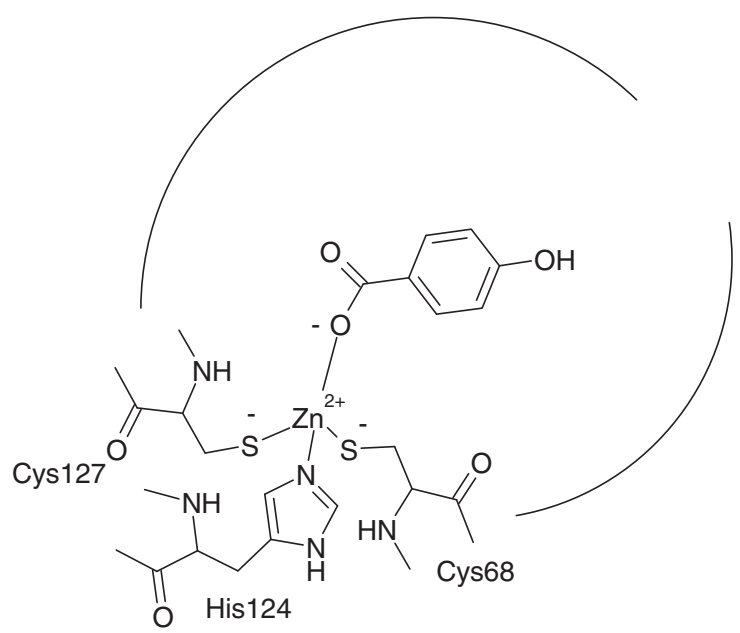

Figure 1. Proposed binding of 4-hydroxybenzoate $19\left(K_{\mathrm{I}}\right.$ of $\left.9.5 \mathrm{nM}\right)$ to Can2 based on the X-ray crystal structure of the enzyme in adduct with acetate. ${ }^{2} \mathrm{The} \mathrm{Zn}(\mathrm{II})$ is coordinated by residues Cys68, His124, Cys127 and a water molecule in the uninhibited enzyme, which is presumably replaced by the carboxylate inhibitor. ${ }^{2}$ The half circles represent the active site channel of the enzyme, which is aligned with various residues in Can2 and Nce103, explaining the different affinity of the variously substituted carboxylates for the two enzymes.
Cys127 and a water molecule in the uninhibited enzyme. This water molecule/hydroxide ion is presumably replaced by the carboxylate inhibitor, generating $\mathrm{Zn}(\mathrm{II})$ in a stable tetrahedral geometry. ${ }^{27}$ Acetate binds in this way to the enzyme. ${ }^{2}$ In addition, the organic scaffold of the inhibitor with its various moieties substituting it, surely interact with the active site channel (shown schematically by the two arches from Fig. 1) in different ways, explaining both the difference of affinity of these inhibitors for Can2 and Nce103 (since the amino acids are different in the two active sites), as well as the wide range variation (from hundreds of micromolar to low nanomolar affinities) of the inhibitory power for diverse derivatives (e.g., aliphatic versus aromatic carboxylates; variously substituted benzoic acids, etc.).

In conclusion, in this Letter we studied the inhibition of the $\beta$ CAs from the pathogenic fungi C. neoformans (Can2) and C. albicans (Nce103) with a series of 25 branched aliphatic and aromatic carboxylates. hCA I and II were also included in the study for comparison. Aliphatic carboxylates were generally ineffective (millimolar) hCA I and II inhibitors and low micromolar/submicromolar $\beta$-CA inhibitors. The aromatic carboxylates were micromolar inhibitors of the four enzymes but some of them showed low nanomolar activity against the fungal pathogenic enzymes. 4-Hydroxy- and 4-methoxy-benzoate inhibit Can2 with $K_{\mathrm{I}} \mathrm{S}$ of 9.5-9.9 nM. Interesting structure-activity relationship for the inhibition of the four enzymes with these carboxylates have also been evidenced although they are not always easy to be interpreted due to the scarcity of crystal structures of $\beta$-CAs in adducts with inhibitors. Furthermore, derivatization of the $\mathrm{COOH}$ moiety as methyl ester, hydroxamate, hydrazide and carboxamide for both aliphatic and aromatic carboxylic acids led to very interesting CA inhibitory effects against both the $\alpha$ - and $\beta$-CAs investigated here, opening thus new research directions for the design of non-sulfonamide inhibitors targeting these enzymes.

\section{Acknowledgments}

We thank Professor Clemens Steegborn (Bayreuth University, Germany) for the gift of Can2 cDNA. This research was financed 
in part by a grant of the 7th Framework Programme of the European Union (the Metoxia project to A.S. and C.T.S.), and by MRC and bbsrc grants (to F.A.M.).

\section{References and notes}

1. (a) Innocenti, A.; Vullo, D.; Scozzafava, A.; Casey, J. R.; Supuran, C. T. Bioorg. Med. Chem. Lett. 2005, 15, 573; (b) Innocenti, A.; Hall, R. A.; Schlicker, C.; Mühlschlegel, F. A.; Supuran, C. T. Bioorg. Med. Chem. 2009, 17, 2654.

2. Schlicker, C.; Hall, R. A.; Vullo, D.; Middelhaufe, S.; Gertz, M.; Supuran, C. T.; Muhlschlegel, F. A.; Steegborn, C. J. Mol. Biol. 2009, 385, 1207.

3. (a) Supuran, C. T. Nat. Rev. Drug Disc. 2008, 7, 168; (b) Supuran, C. T. Bioorg. Med. Chem. Lett. 2010, 20, 3467.

4. Xu, Y.; Feng, L.; Jeffrey, P. D.; Shi, Y.; Morel, F. M. Nature 2008, 452, 56.

5. (a) Tripp, B. C. Smith, K. S.; Ferry, J. G. J. Biol. Chem. 2001, 276, 48615; (b) Smith K. S.; Ferry, J. G. FEMS Microbiol. Rev. 2000, 24, 335; (c) Ferry, J. G. Biochim. Biophys. Acta 2010, 1804, 374; (d) Ferry, J. G.; Supuran, C. T. Mechanism and Inhibition of the $\beta$-Class and $\gamma$-Class Carbonic Anhydrases. In Drug Design of Zinc-Enzyme Inhibitors: Functional, Structural, and Disease Applications; Supuran, C. T., Winum, J. Y., Eds.; John Wiley Sons: Hoboken, 2009; pp 285-300; (e) Zimmerman, S. A.; Ferry, J. G.; Supuran, C. T. Curr. Top. Med. Chem. 2007, 7, 901.

6. (a) Hall, R. A. Mühlschlegel, F. A. Fungal and Nematode Carbonic Anhydrases: Their Inhibition in Drug Design. In Drug Design of Zinc-Enzyme Inhibitors: Functional, Structural, and Disease Applications; Supuran, C. T., Winum, J. Y., Eds.; John Wiley Sons: Hoboken, 2009; pp 301-322; (b) Ohndorf, U. M.; Schlicker C. Steegborn, C. Crystallographic Studies on Carbonic Anhydrases from Fungal Pathogens for Structure-assisted Drug Development. In Drug Design of ZincEnzyme Inhibitors: Functional, Structural, and Disease Applications; Supuran, C. T., Winum, J. Y., Eds.; John Wiley Sons: Hoboken, 2009; pp 323-334.

7. (a) Supuran, C. T.; Scozzafava, A.; Casini, A. Med. Res. Rev. 2003, 23, 146; (b) Supuran, C. T.; Scozzafava, A.; Conway, J. Carbonic Anhydrase-Its Inhibitors and Activators; CRC Press: Boca Raton (FL), USA, 2004. pp 1-364; (c) Supuran, C. T. Scozzafava, A Expert Opin. Ther. Patents 2002, 12, 217: (d) Scozzafava, A. Mastrolorenzo, A.; Supuran, C. T. Expert Opin. Ther. Patents 2004, 14, 667.

8. (a) Klengel, T.; Liang, W. J.; Chaloupka, J.; Ruoff, C.; Schropel, K.; Naglik, J. R.; Eckert, S. E.; Mogensen, E. G.; Haynes, K.; Tuite, M. F.; Levin, L. R.; Buck, J.; Mühlschlegel, F. A. Curr. Biol. 2005, 15, 2021; (b) Bahn, Y. S.; Cox, G. M.; Perfect, J. R.; Heitman, J. Curr. Biol. 2005, 15, 2013.

9. (a) Mogensen, E. G.; Janbon, G.; Chaloupka, J.; Steegborn, C.; Fu, M. S.; Moyrand F.; Klengel, T.; Pearson, D. S.; Geeves, M. A.; Buck, J.; Levin, L. R.; Mühlschlegel, F. A. Eukaryot. Cell 2006, 5, 103; (b) Bahn, Y. S.; Mühlschlegel, F. A. Curr. Opin. Microbiol. 2006, 9, 572; (c) Innocenti, A.; Mühlschlegel, F. A.; Hall, R. A.; Steegborn, C.: Scozzafava, A.; Supuran, C. T. Bioorg. Med. Chem. Lett. 2008, 18, 5066; (d) Isik, S.; Kockar, F.; Arslan, O.; Ozensoy Guler, O.; Innocenti, A.; Supuran, C. T. Bioorg. Med. Chem. Lett. 2008, 18, 6327.

10. Syrjänen, L.; Tolvanen, M.; Hilvo, M.; Olatubosun, A.; Innocenti, A.; Scozzafava, A.; Leppiniemi, J.; Niederhauser, B.; Hytönen, V. P.; Gorr, T. A.; Parkkila, S.; Supuran, C. T. BMC Biochem. 2010, 11, 28.

11. (a) Nishimori, I.; Minakuchi, T.; Kohsaki, T.; Onishi, S.; Takeuchi, H.; Vullo, D.; Scozzafava, A.; Supuran, C. T. Bioorg. Med. Chem. Lett. 2007, 17, 3585; (b) Isik, S.; Kockar, F.; Aydin, M.; Arslan, O.; Ozensoy Guler, O.; Innocenti, A.; Scozzafava, A.; Supuran, C. T. Bioorg. Med. Chem. 2009, 17, 1158.

12. (a) Minakuchi, T.; Nishimori, I.; Vullo, D.; Scozzafava, A.; Supuran, C. T. J. Med. Chem. 2009, 52, 2226; (b) Nishimori, I.; Minakuchi, T.; Vullo, D.; Scozzafava, A.; Innocenti, A.; Supuran, C. T. J. Med. Chem. 2009, 52, 3116.

13. (a) Cronk, J. D.; Rowlett, R. S.; Zhang, K. Y.; Tu, C.; Endrizzi, J. A.; Lee, J.; Gareiss, P. C.; Preiss, J. R. Biochemistry 2006, 45, 4351; (b) Rowlett, R. S. Biochim. Biophys. Acta 2010, 1804, 362

14. Innocenti, A.; Hall, R. A.; Schlicker, C.; Scozzafava, A.; Steegborn, C.; Mühlschlegel, F. A.; Supuran, C. T. Bioorg. Med. Chem. 2009, 17, 4503.

15. (a) Innocenti, A.; Winum, J.-Y.; Hall, R. A.; Mühlschlegel, F. A.; Scozzafava, A.; Supuran, C. T. Bioorg. Med. Chem. Lett. 2009, 19, 2642; (b) Innocenti, A.; Leewattanapasuk, W.; Mühlschlegel, F. A.; Mastrolorenzo, A.; Supuran, C. T. Bioorg. Med. Chem. Lett. 2009, 19, 4802.
16. (a) Supuran, C. T. Curr. Pharm. Des. 2010, 16, 3233; (b) Nishimori, I.; Minakuchi, T.: Maresca, A. Carta, F. Scozzafava, A.; Supuran, C. T. Curr Pharm. Des. 2010 16, 3300; (c) Winum, J. Y.; Kohler, S.; Supuran, C. T. Curr. Pharm. Des. 2010, 16, 3310 .

17. Burghout, P.; Vullo, D.; Scozzafava, A.; Hermans, P. W. M.; Supuran, C. T. Bioorg. Med. Chem. 2011, 19, 243.

18. (a) Maresca, A.; Temperini, C.; Vu, H.; Pham, N. B.; Poulsen, S. A.; Scozzafava, A.; Quinn, R. J.; Supuran, C. T. J. Am. Chem. Soc. 2009, 131, 3057; (b) Maresca, A.; Temperini, C.; Pochet, L.; Masereel, B.; Scozzafava, A.; Supuran, C. T. J. Med. Chem. 2010, 53, 335.

19. (a) Maresca, A.; Supuran, C. T. Bioorg. Med. Chem. Lett. 2010, 20, 4511; (b) Maresca, A.; Scozzafava, A.; Supuran, C. T. Bioorg. Med. Chem. Lett. 2010, 20 7255.

20. Innocenti, A.; Supuran, C. T. Bioorg. Med. Chem. Lett. 2010, 20, 6208

21. Buffers and carboxylates 1-27 (as sodium salts) were of highest purity available, and were used without further purification, being purchased from Sigma-Aldrich (Milan, Italy). hCA I and II were prepared in recombinant form as described earlier, ${ }^{18}$ whereas Can2 and Nce103 were recombinant, purified enzymes obtained as described by Mühlschlegel's and Steegborn's groups. ${ }^{6-8}$

22. An Applied Photophysics stopped-flow instrument has been used for assaying the CA catalysed $\mathrm{CO}_{2}$ hydration activity. Phenol red (at a concentration of $0.2 \mathrm{mM}$ ) has been used as indicator, working at the absorbance maximum of $557 \mathrm{~nm}$, with 10-20 mM Hepes ( $\mathrm{pH} 7.5$, for the $\alpha$-CAs) or TRIS ( $\mathrm{pH} 8.3$, for the $\beta$-CAs) as buffers, and $20 \mathrm{mM} \mathrm{Na}_{2} \mathrm{SO}_{4}$ or $20 \mathrm{mM} \mathrm{NaClO}_{4}$ (for maintaining constant the ionic strength), following the initial rates of the CA-catalyzed $\mathrm{CO}_{2}$ hydration reaction for a period of $10-100 \mathrm{~s}$. The $\mathrm{CO}_{2}$ concentrations ranged from 1.7 to $17 \mathrm{mM}$ for the determination of the kinetic parameters and inhibition constants. For each inhibitor at least six traces of the initial 5-10\% of the reaction have been used for determining the initial velocity. The uncatalyzed rates were determined in the same manner and subtracted from the total observed rates. Stock solutions of inhibitor $(1 \mathrm{mM})$ were prepared in distilled-deionized water and dilutions up to $0.1 \mathrm{nM}$ were done thereafter with distilled-deionized water. Inhibitor and enzyme solutions were preincubated together for $15 \mathrm{~min}$ at room temperature prior to assay, in order to allow for the formation of the E-I complex. The inhibition constants were obtained by non-linear least-squares methods using PRISM 3, whereas the kinetic parameters for the uninhibited enzymes from Lineweaver-Burk plots, as reported earlier, ${ }^{1,10,12,20}$ and represent the mean from at least three different determinations.

23. (a) Di Fiore, A.; Monti, S. M.; Hilvo, M.; Parkkila, S.; Romano, V.; Scaloni, A. Pedone, C.; Scozzafava, A.; Supuran, C. T.; De Simone, G. Proteins 2009, 74, 164 (b) Alterio, V.; Di Fiore, A.; D’Ambrosio, K.; Supuran, C. T.; De Simone, G. In Xray Crystallography of CA Inhibitors and its Importance in Drug Design in Drug Design of Zinc-enzyme Inhibitors: Functional, Structural, and Disease Applications: Supuran, C. T., Winum, J. Y., Eds.; Wiley: Hoboken, 2009; pp 73-138.

24. Derivatives 8a-8d and 20a-20d have been prepared from the corresponding acyl chlorides by reaction with nucleophiles or by direct esterification (for the methyl esters) of the acids.

2-Ethylhexanehydrazide 8c: yield $68 \%$ yield; mp $95{ }^{\circ} \mathrm{C}$ ( Lit. $\left.^{25} 91-93{ }^{\circ} \mathrm{C}\right)$; silica gel TLC $R_{f} 0.15$ (ethyl acetate/n-hexane $\left.70 \% \mathrm{v} / \mathrm{v}\right) ; \delta_{\mathrm{H}}\left(400 \mathrm{MHz}\right.$, DMSO- $\left.d_{6}\right) 0.97$ $\left(6 \mathrm{H}, 2 \times \mathrm{CH}_{3}\right), 1.30(4 \mathrm{H}, \mathrm{m}), 1.51(4 \mathrm{H}, \mathrm{m}), 2.34(1 \mathrm{H}, \mathrm{m}, \mathrm{CH}), 4.20(2 \mathrm{H}, \mathrm{br} \mathrm{s}$, exchange with $\left.\mathrm{D}_{2} \mathrm{O}, \mathrm{NH}_{2}\right), 9.60\left(1 \mathrm{H}, \mathrm{s}\right.$, exchange with $\left.\mathrm{D}_{2} \mathrm{O}, \mathrm{CONH}\right) ; \delta_{\mathrm{C}}(100 \mathrm{MHz}$, DMSO- $\left.d_{6}\right) 172.2(\mathrm{C}=\mathrm{O}), 47.9,32.0,30.2,26.5,23.0,16.2,12.0$. $\mathrm{N}$-Hydroxy-4-methoxybenzamide 20b: $55 \%$ yield; mp $157^{\circ} \mathrm{C}$ (Lit. ${ }^{26} 153$ $155^{\circ} \mathrm{C}$ ); silica gel TLC $R_{f} 0.16$ (ethyl acetate $/ n$-hexane $\left.70 \% \mathrm{v} / \mathrm{v}\right) ; \delta_{\mathrm{H}}(400 \mathrm{MHz}$ DMSO-d $\left.d_{6}\right) 3.83\left(3 \mathrm{H}, \mathrm{s}, \mathrm{CH}_{3}\right), 7.00(2 \mathrm{H}, \mathrm{d}, J 8.8, \mathrm{Ar}-\mathrm{H}), 7.82(2 \mathrm{H}, \mathrm{d}, J 8.8, \mathrm{Ar}-\mathrm{H})$ $8.92\left(1 \mathrm{H}\right.$, br s, exchange with $\left.\mathrm{D}_{2} \mathrm{O}, \mathrm{NH}\right), 10.30\left(1 \mathrm{H}, \mathrm{s}\right.$, exchange with $\left.\mathrm{D}_{2} \mathrm{O}, \mathrm{OH}\right)$; $\delta_{\mathrm{C}}\left(100 \mathrm{MHz}, \mathrm{DMSO}-d_{6}\right) 169.3(\mathrm{C}=0), 164.0,128.1,127.1,114.2,56.0$.

25. Yu, D. D.; Forman, B. M. Bioorg. Med. Chem. Lett. 2005, 15, 1311

26. Couturier, M.; Tucker, J. L.; Proulx, C.; Boucher, G.; Dube, P.; Andresen, B. M.; Ghosh, A. J. Org. Chem. 2002, 67, 4833.

27. Supuran, C. T.; Winum, J. Y. Introduction to Zinc Enzymes as Drug Targets. In Drug Design of Zinc-enzyme Inhibitors: Functional, Structural, and Disease Applications; Supuran, C. T., Winum, J. Y., Eds.; Wiley: Hoboken, 2009; pp 3-12. 